Kazimierz Adamczyk

Uniwersytet Jagielloński

kazimierz.adamczyk@uj.edu.pl

\title{
Żydówki w relacjach Polek więzionych w KL Ravensbrück
}

\section{Jewish Women in Accounts of Polish Women Inmates of KL Ravensbrück}

\begin{abstract}
Scholars researching the lives of inmates rescued from German concentration camps and medically treated in Sweden write about anti-Semitic attitudes among the rescued Poles. The article analyzes memories and testimonies of Polish women kept in Ravensbrück chosen with respect to mentions of the Jewish women homicide. The Polish women who directly experienced the Nazi terror adopt the role of a victim - a camp inmate - and, at the same time, a witness of the Holocaust. The Jewish women's fate is most often absent from their accounts or signaled only by brief remarks. The memories of Janina Fabierkiewicz-Szyrkowska, Karolina Lanckorońska, Zofia Krzyżanowska and Maria Rutkowska-Kurcyuszowa stand out against this dominating silence as to the Jews' situation in the camp. These accounts are devoted the most attention in the article.
\end{abstract}

Keywords: Ravensbrück, Polish women inmates, Jewish women inmates, anti-Semitism, testimony, Holocaust

Streszczenie: Badacze losów więźniów uratowanych z niemieckich obozów koncentracyjnych i leczonych w Szwecji piszą o antysemickich postawach wśród ocalonych Polek i Polaków. W artykule analizowane są wspomnienia i zeznania Polek więzionych w Ravensbrück dobrane ze względu na pojawiające się w nich odniesienia do mordu dokonanego na żydowskich kobietach. Polkom bezpośrednio poddanym terrorowi nazistowskiemu przypada rola ofiary-więźnia obozu i jednocześnie świadka Zagłady. W ich relacjach los Żydówek jest najczęściej nieobecny lub sygnalizowany jedynie kilkuzdaniową uwagą. Na tle tego dominującego milczenia o sytuacji Żydówek w obozie wyróżniają się wspomnienia Janiny Fabierkiewicz-Szyrkowej, Karoliny Lanckorońskiej, Zofii Krzyżanowskiej, Marii Rutkowskiej-Kurcyuszowej. W artykule relacjom tym poświęcono najwięcej uwagi.

Słowa kluczowe: Ravensbrück, więźniarki-Polki, więźniarki-Żydówki, antysemityzm, świadectwo, Zagłada 
„Ludzkiego cierpienia nie da się stopniować w jakikolwiek sposób"1

Yehuda Bauer

Położony 80 kilometrów od Berlina FKL Ravensbrück powstał w marcu 1939 roku. Jego pierwszymi więźniarkami były niemieckie działaczki polityczne oraz niemieckie Żydówki. Polki trafiły do obozu zaraz po rozpoczęciu hitlerowskiej agresji na Polskę. Uwięziono tu wówczas przede wszystkim działaczki organizacji oświatowych i polonijnych z terenów III Rzeszy, a wkrótce przedstawicielki inteligencji polskiej aresztowane w pierwszych miesiącach okupacji. W ciągu sześciu lat istnienia teren obozu powiększył się kilkakrotnie, a ogólna liczba uwięzionych w nim kobiet wyniosła ponad 130 tysięcy. W czasie trwania wojny warunki życia zmieniały się dramatycznie, a pod koniec jego istnienia obóz przekształcił się w wielkie pole śmierci², miejsce zagłady bezpośredniej, co związane jest ze zbudowaniem komory gazowej ${ }^{3}$ i zabijaniem w niej Żydówek oraz kobiet innych narodowości niezdolnych już do pracy, wycieńczonych, a często znajdujących się w stanach przedagonalnych. Do komory gazowej przewożono je z mieszczącego się kilkaset metrów od głównego obozowego kompleksu Jugendlagru. Był to obóz młodzieżowy przekształcony w swoistą poczekalnię do śmierci. Szacuje się, iż od 22 stycznia do 14 kwietnia przebywało w nim około 8 tysięcy kobiet, z tej liczby zagazowano lub zamordowano w inny sposób 5,5 tysięcy więźniarek4 .

Uwięzione w Ravensbrück kobiety pochodziły z 27 narodów. Śmiertelność wynosiła około 50 procent. Najliczniejszą populację więźniarek stanowiły

${ }^{1}$ Y. Bauer, Przemyśleć Zagtadę, tłum. J. Giebułtowski, J. Surewicz, Warszawa 2016, s. 32.

2 „Trupy leżały wszędzie. Noszono je bezustannie na tragach i ładowano na ciężarówki, miejscowe krematorium nie nadążało już z paleniem, choć krwawy wieniec płomieni otaczał komin w dzień i noc”. Z. Krzyżanowska, Czarna flaga, Warszawa 1960, s. 149.

${ }^{3}$ Komora gazowa uruchomiona została na początku listopada 1944 roku i działała do 30 marca 1945 roku. Gazowanie więźniarek rozpoczęto jednakże w Ravensbrück wcześniej. Do tego celu wykorzystywano zaadaptowane do zbrodniczego celu auto, a później stary holenderski wagon kolejowy. W urządzeniach tych uśmiercano kobiety od lata 1944 roku. Zob. W. Kiedrzyńska, Ravensbrück. Kobiecy obóz koncentracyjny, Warszawa 1965, s. 115-117. Wcześniej wysyłano transporty kobiet do komór gazowych w innych obozach koncentracyjnych. Judith Buber Agassi podaje, iż komory gazowe wybudowane w Ravensbrück uruchomiono 4 stycznia 1945 roku. Zob. taż, Jewish Woman Prisoners of Ravensbrück: Who Were They?, Lubbock, Texas 2014, s. 138.

${ }^{4}$ J.B. Agassi, dz. cyt., s. 233. 
Polki, Niemki i Żydówki. Śmiertelność Żydówek sięgała 70 procent ${ }^{5}$. Tylko w pierwszej fazie istnienia lagru miały one swoją blokową, Olgę Benario-Prestes, która mogła się poruszać swobodnie po terenie obozu. Po likwidacji pierwszej grupy żydowskich więźniarek następne nie miały już swych reprezentantek w obozowym „samorządzie”. Traktowano je najgorzej, podobnie jak i w innych nazistowskich obozach. Dostawały dwukrotnie mniejsze racje żywnościowe, pracowały w karnym komandzie, na początku istnienia obozu były odizolowane od innych więźniarek, za próbę kontaktu z nimi stosowano okrutne kary. Nie mogły otrzymywać paczek, które decydowały o przeżyciu i miejscu w blokowej hierarchii ${ }^{6}$. Od lutego 1942 roku podlegały planowej eksterminacji. Niemal wszystkie więzione tu Żydówki zostały w ciągu kilku najbliższych miesięcy zamordowane. Tym samym - zgodnie z rozkazem Heinricha Himmlera - FKL Ravensbrück stał się obozem aryjskim ${ }^{7}$.

Po kilkunastu miesiącach, a zwłaszcza od września 1944 roku napływały do niego nowe transporty Żydówek: z Polski (transport z getta częstochowskiego, piotrkowskiego, łódzkiego), z Rumunii, Słowacji i w największej liczbie - z Węgier, a także więźniarki ewakuowane z Auschwitz-Birkenau, w tym w marszu śmierci, oraz późną jesienią z Budapesztu. Począwszy zatem od lata 1944 kobiety narodowości żydowskiej stanowiły najliczniejszą grupę nowo przybyłych. Dla oddania masowości tego napływu Sara Helm posługuje się biblijnym określeniem - pisze o potopie Żydówek w Ravensbrück. Silne i młode kobiety wykorzystywano do niewolniczej pracy w fabrykach.

5 Tamże, s. 217.

${ }^{6} \mathrm{O}$ uprzywilejowanej pozycji kobiet otrzymujących zasobne paczki z domu i wzroście ich pozycji, w związku z możliwością kupowania wielu usług, pisze Wanda Dobaczewska. Wyraża ona opinię, iż w latach 1943-1944 żadna z Polek nie zaznała głodu. W. Dobaczewska, Kobiety z Ravensbrück, Warszawa 1946, s. 42-41. Monografistka Ravensbrück podaje, że otrzymywanie paczek dozwolone było od końca 1942 roku. Zob. S. Helm, Kobiety z Ravensbrück. Zycie i śmierć w hitlerowskim obozie koncentracyjnym dla kobiet, tłum. K. Bażyńska-Chojnacka, P. Chojnacki, Warszawa 2017, s. 338.

7 Pierwszy transport Żydówek przeznaczonych do uśmiercenia przybył w nocy z 1 na 2 lutego 1942 roku. Akcja trwała do lipca tego roku. Wraz z Żydówkami wywożono kobiety chore umysłowo i niezdolne do pracy. Kobiety mordowano w Buch pod Berlinem i w różnych obozach koncentracyjnych w komorach gazowych. Zob. W. Kiedrzyńska, dz. cyt., s. 112-113. Lęk i niepewność co do losów wywiezionych kobiet oraz poznanie ich losu odnajdziemy w zeznaniach więźniarek oraz ich wspomnieniach. Na przykład w książce Marii Wysznackiej przeczytamy: „7 lutego zaczęło się wywożenie z obozu. Najpierw ciężarówkami wywożono Żydówki. Być może, że młodsze i silniejsze jechały istotnie do sypania okopów, cel podróży był jednak dobrze wiadomy: ładowano przecież na samochody żywe trupy. Przed oczami stał ciągle lęk przed Wielką Niewiadomą. Dokąd powiozą. A może popędzą? Jak zostawią, to co będzie na końcu?”. Zob. M. Wysznacka, Bestie i ludzie (Ravensbrück-Szwecja), Włocławek 1947, s. 46. Kilkudniowa różnica odnotowanych dat pomiędzy zapisem w monografii a wspomnieniu z punktu widzenia wiarygodności wspomnienia Wysznackiej jest nieistotna. Judith Buber Agassi pisze: „At the time of Himmler's inspection on 19 March 1943, no legitimate Jewish woman prisoners were supposed to be in camp. There was no longer a Judenblock". Zob. J.B. Agassi, dz. cyt., s. 174. 
Zewnętrznych komand podlegających administracji obozu było kilkadziesiąt ${ }^{8}$, i panowały w nich skrajnie różne warunki egzystencji. Żydówki pracowały tu z kobietami innych narodowości i kontakt między nimi a pozostałymi więźniarkami, w tym Polkami, był w tych komandach łatwiejszy.

Jedynie zdecydowana mniejszość żydowskich kobiet pozostawała w głównym obozie w Ravensbrück. Umieszczono je w bloku Żydówek i bloku Francuzek. Oznaczone zostały żółtą gwiazdą. Szczególnie tragiczne były warunki, w jakich odbywał kwarantannę w listopadzie 1944 roku transport 3-4 tysięcy. Stłoczono je w namiocie na placu obozowym. Zimno, głód, choroby, wprost niewyobrażalny brud, brak wody - wszystko to doprowadziło do ich masowej śmierci. Obecność w obozie tych nieszczęsnych kobiet nie mogła zostać niezauważona przez więźniarki innych narodowości.

W ostatnich miesiącach swego istnienia, a właściwie od dostarczonych tu transportów węgierskich Żydówek wyselekcjonowanych w Auschwitz i mieszkanek Warszawy przywiezionych po klęsce powstania, lager w Ravensbrück stał się obozem tranzytowym, targiem niewolniczek dla niemieckiego biznesu wojennego ${ }^{9}$. Dramatyczna była też sytuacja więźniarek w ostatnich tygodniach FKL Ravensbrück, i to zarówno tych ginących w kolejnych marszach ewakuacyjnych, eskortowanych przez SS-manów, jak i kobiet chorych, które w obozie pozostały do wyzwolenia przez Armię Czerwoną. Słowem, nie ma jednego obozu koncentracyjnego Ravensbrück, tak jak nie było jednego Auschwitz ${ }^{10}$. Panujące w nich warunki zmieniały się dynamicznie. Polki trafiające do FKL Ravensbrück - w zależności od czasu i miejsca uwięzienia w obozie - miały różne szanse dostrzeżenia i spotkania izolowanych w nim Żydówek.

\section{II}

O istnienie obozu w Ravensbrück wiedziano w wolnym świecie już w czasie wojny. Budził on zainteresowanie między innymi z powodu akcji informacyjnej polskich więźniarek - to dzięki nim alianci dowiedzieli się o prowadzeniu

8 Szczegółowe wyliczenie komand fabrycznych wraz ich składem narodowościowym podaje W. Kiedrzyńska, dz. cyt., s. 143-162.

9 Zob. J.B. Agassi, dz. cyt., s. 39.

${ }_{10}$ Zmieniające się warunki w obozie, a także zmiany jego charakteru z obozu koncentracyjnego na obóz tranzytowy oraz, po części, obóz bezpośredniej zagłady, odnotowują w relacjach liczne więźniarki. Na przykład szczegółowa relacja Marii Moldenhawer zarchiwizowana w Bibliotece Uniwersytetu w Lund, zeznanie numer 420, http://www.alvin-portal.org/alvin/view. jsf?pid=alvin-record\%3A103561\&dswid=-7911, dostęp: 6.03.2018. Wspomniana już Krzyżanowska pisze: „Zdrowo i czysto wyglądały i inne kobiety w sztubie. Prawie wszystkie miały długie włosy i przyzwoitą odzież. Byłam zdezorientowana. Jaka jest prawda o obozie? Co jest rzeczywistością: tamten namiot - czy barak? Transport z fabryki - czy mieszkanki siedemnastki? Które z doświadczeń jest złudzeniem ?”. Zob. taż, dz. cyt., s. 70. Każda z monografistek obozu: Sara Helm, Judith Buber Agassi, Wanda Kiedrzyńska wyróżnia kilka okresów w dziejach lagru. 
w obozie zbrodniczych eksperymentów medycznych ${ }^{11}$, w wyniku których uwięzione kobiety skazywano na trwałe kalectwo, a czasem śmierć, przez wywoływanie zakażeń, powodowanie wielokrotnych złamań i ubytków kości. Pseudomedycznym eksperymentom poddano w obozie 174 polskie więźniarki polityczne, na których ciążyły wyroki śmierci, oraz pięć kobiet innej narodowości, w tym jedną Żydówkę ${ }^{12}$.

To „naukowe” bestialstwo zadecydowało o „ponurej sławie” Ravensbrück. Zeznania złożone przez ofiary zabiegów, napisane wspomnienia i relacje zdominowały polską pamięć o tym obozie koncentracyjnym. Splotły się one nierozerwalnie $\mathrm{z}$ "narracjami godnościowymi”, albo - powiedzmy wprost - patriotycznymi „lekcjami” podkreślającymi heroizm, solidarność i pracę kulturalną polskich więźniarek politycznych ${ }^{13}$, wśród których znalazło się dużo inteligentek oraz młodych dziewcząt działających w różnych formach konspiracji. Kilkaset z nich przywieziono z wyrokami śmierci w tak zwanych Sondertransportach z Lublina, Warszawy i Krakowa ${ }^{14}$. W obozie wykonano egzekucje na ponad 160 Polkach. Zabito je strzałem z rewolweru w potylicę ${ }^{15}$. Działaczki podziemnego państwa polskiego nie stanowiły większości wśród polskich więźniarek, nie były też najliczniejszą grupą polskich ofiar. Obok politycznych znalazły się tu kobiety osadzone za przestępstwa przeciwko mieniu niemieckiemu, ucieczkę z przymusowych robót, czyny kryminalne. Maria Wysznacka tak pisze o Polkach uratowanych dzięki akcji hrabiego Folkego Bernadottego ${ }^{16}$ :

A trzeba ciągle pamiętać, że Polki, które znalazły się w Szwecji i przyjechały tu z obozu koncentracyjnego, to był element społecznie i moralnie bardzo niejednolity. Obok elementu ideowego, był tam i element przestępczy, obok jednostek wykształconych były analfabetki, obok kobiet, którym życie dało warunki do osiągnięcia wyższego stopnia kultury, były kobiety, które los upośledził, które nie miały możności

${ }^{11}$ Wiadomości z obozu zostały nagłośnione przez zwolnioną z Ravensbrück, Aka Kołodziejczyk, obywatelkę USA, za pośrednictwem listów wysyłanych nielegalnie z lagru, dzięki kontaktowi z jeńcami francuskimi, i za pośrednictwem listów pisanych moczem do rodzin w Polsce. Informacje dotarły do BBC i Międzynarodowego Czerwonego Krzyża. Zob. W. Kiedrzyńska, dz. cyt., s. 212-213.

12 Zob. S. Sterkowicz, Kobiecy obóz koncentracyjny Ravensbrück, Włocławek 2006.

13 Takimi książkami pogadankami autorstwa byłych więźniarek obozu, z dominującą funkcją dydaktyczną, są D. Brzosko-Mędryk „Mury” w Ravensbrück, Warszawa 1979 i Mury. Harcerska konspiracyjna drużyna w Ravensbrück. Wspomnienia, materiaty do gawęd, oprac. J. Kantor, red. nauk. A. Szefer, Katowice 1986.

14 Więźniarkom politycznym z tych transportów nadano numery od 7521 do 7935. Zob. S. Helm, dz. cyt., s. 237.

15 Zob. W. Kiedrzyńska, dz. cyt., s. 171-186.

16 Zob. S. Persson, Biate autobusy. Pakt z Himmlerem i niezwykta akcja ratowania więźniów obozów, tłum. Z. Kunert, Warszawa 2012. 
czerpać ze źródeł kultury i pozostawały poza jej wpływami. Były to skutki niedemokratycznych form życia w Polsce przedwojennej a następnie kataklizmu wojennego ${ }^{17}$.

W relacjach politycznych więźniarek przebywających w obozie kilka lat i idealizujących wszystko, co związane było z Polską, spotkać można krytyczne oceny zachowania kobiet przywiezionych po upadku powstania warszawskiego. W relacji Janiny Fabierkiewicz-Szyrkowej czytamy:

W obozie gloryfikowało się wszystko, co polskie, miało się szczególny kult dla walki rodaków i ich bohaterstwa. Stąd każdy fakt, który odbiegał od naszych wyobrażeń i idealnego obrazu, bardzo bolał. Za niektóre kobiety z ewakuowanej Warszawy było nam po prostu wstyd $\mathrm{d}^{18}$.

Z kolei Wanda Dobaczewska nie waha się przekazać krytycznych uwag o zachowaniu niektórych polskich więźniarek. Pisząc o czterech polskich blokach, w których funkcyjnymi zostały Polki, komentuje: „Nowym dygnitarkom woda sodowa szybko uderzyła do głowy"19. Michalina Woźniakówna z wahaniem ujawnia nazwisko Rozmiarek - polskiej oprawczyni w bloku 21: „Długo zastanawiam się, czy powinnam tu pisać o tej sprawie, ale doszłam do wniosku, że tak, bezwzględnie, a nawet muszę"20. Polska historia o Ravensbrück utrwalona została przede wszystkim przez więźniarki ideowe, właśnie one piszą o patriotycznych postawach Polek, i jeżeli w ogóle, to najczęściej jedynie w kilkuzdaniowych napomknieniach krytykują zachowanie niektórych swoich rodaczek.

Do 1941 roku polskie więźniarki nie zajmowały żadnych funkcyjnych stanowisk w obozie. Dopiero kiedy Helena Korewina została tłumaczką głównej dozorczyni Johanny Langefeld i - jak pisze Kiedrzyńska - „dyspozytorką pracy w samorządzie więźniarskim" ${ }^{21}$, umożliwiła rodaczkom objęcie wielu funkcji w lagrze. Okres uprzywilejowania Polek w strukturze obozu trwał trzy lata i zakończył się wraz z aresztowaniem Korewiny. Zajmowanie stanowisk w lagrze przekładało się na lepszą sytuację Polek, wynikłą z możliwości „organizowania” żywności, odziėzy, a nawet lekarstw, i niewątpliwie ograniczało stale obecną groźbę szykan ${ }^{22}$. Krzyżanowska wspomina: „Pozbawione przywilejów, straciłyśmy posiadane dotąd poczucie względnego bezpieczeństwa”’3. Narodowa solidarność Polek postrzegana była przez więźniarki z innych grup jako wykorzystywanie

${ }_{17}$ M. Wysznacka, dz. cyt., s. 65.

18 J. Fabierkiewicz-Szyrkowa, Gdzie nie śpiewaty ptaki..., Warszawa 1972, s. 77.

19 W. Dobaczewska, Spoteczeństwo nie z tej ziemi, Łódź 1979, s. 30.

${ }^{20}$ M. Woźniakówna, Obóz koncentracyjny dla kobiet Ravensbrück, Poznań 1946, s. 110.

${ }^{21}$ W. Kiedrzyńska, dz. cyt., s. 35-36.

22 A. Truszkowska-Kuliniczowa, Mój wiek XX. Wspomnienia, Szczecin 2004, s. 76. Autorka podaje, iż Helena Korewina wprowadziła około 50 Polek na pozycje funkcyjnych w obozie.

23 Z. Krzyżanowska, dz. cyt., s. 139. 
i nadużywanie stanowisk. Nic nie chroniło jednak przed wszechwładzą obozowego gestapo. $Z$ powodu pomyłki adresowej młoda Polka spędziła w bunkrze, często głodując i będąc pozbawioną światła, 55 dni. Jej list, adresowany na ulicę Smo-

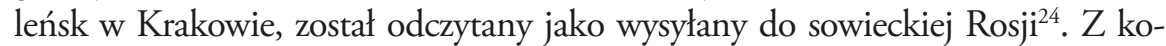
lei Janina Fabierkiewicz-Szyrkowa była zamknięta w bunkrze blisko pół roku² ${ }^{25}$.

\section{III}

Żydówki i Polki - obok Niemek - stanowiły dwie najliczniejsze grupy więźniarek FKL Ravensbrück; w niektórych fazach istnienia obozu całkowicie odseparowane, $\mathrm{w}$ innym czasie pracujące $\mathrm{w}$ tych samych komandach i umierające obok siebie w Jungendlagrze, uśmiercane w obozowej komorze gazowej. Żydówki, bez wyjątku, były skazane na śmierć z powodów rasowych. Wśród Polek znajdowały się więźniarki polityczne z wyrokami śmierci przeznaczone do zbrodniczych medycznych eksperymentów. Polki to ofiary tych samych sprawców zbrodni i jednocześnie świadkinie Zagłady. W wielu wypadkach rozdzielenie tożsamości świadka i ofiary byłoby tutaj zabiegiem sztucznym.

W powojennej prasie szwedzkiej informowano o antysemickich incydentach wśród więźniów ewakuowanych z niemieckich obozów koncentracyjnych. O problemach tych pisze badacz polskiej społeczności w Szwecji:

Już w obozach zarysowała się wyraźna różnica w zachowaniu Polaków i polskich Żydów. Żydówki wskazywały na polski antysemityzm, który miał się tam objawiać. W jednym z artykułów pisano: „(...) z hitlerowskich obozów koncentracyjnych zawleczony został do uchodźców polskich w Szwecji antysemityzm. Przejawy jego były różnorodne, począwszy od niechęci towarzyskiej, a skończywszy na zniewagach słownych i czynnych"26.

Podobne zjawiska zdarzające się wśród męskich ofiar nazizmu opisuje Mordechay Giloh. Skala zjawiska zaskoczyła szwedzkie władze obozów dla uchodźców. Wśród Polaków „nastroje antysemickie były nieskrywane i dominujące”27.

W monografii obozu koncentracyjnego Sarah Helm odnotowała spory i wzajemne oskarżenia Polek i Żydówek, które rywalizowały o miejsce w autobusie oznaczające ewakuację do Szwecji ${ }^{28}$.

${ }^{24}$ Zob. M. Woźniakówna, dz. cyt.

${ }^{25}$ J. Fabierkiewicz-Szyrkowa, dz. cyt., s. 183.

26 A. Kłonczyński, My w Szwecji nie porastamy mchem. Emigranci polscy w Szwecji w latach 1945-1980, Gdańsk 2012, s. 43.

${ }_{27}$ M. Giloh, Odmienne sylwetki przybytych do Szwecji więźniów pochodzenia żydowskiego i nieżydowskiego, ocalatych z obozów koncentracyjnych na ziemiach polskich, „Zagłada Żydów. Studia i Materiały" 2012, nr 8, s. 427-428.

28 S. Helm, dz. cyt., s. 806. 
Tak jednoznaczne stwierdzenie trwałości postaw antysemickich pośród ewakuowanych do Szwecji polskich więźniarek i więźniów niemieckich obozów koncentracyjnych skłania do przyjrzenia się pozostawionym przez Polki z Ravensbrück zeznaniom i wspomnieniom.

Przedmiotem mojego namysłu są zarówno świadectwa-zeznania kobiet uwolnionych z Ravensbrück zarchiwizowane w Bibliotece Uniwersyteckiej w Lund w Szwecji, jak i książki wspomnieniowe wydane po wojnie w Polsce. Nieliczne z nich odznaczają się walorami literackimi. Takim dziełem autobiograficznym i jednocześnie literackim jest wspomniana już Czarna flaga Zofii Krzyżanowskiej. Literackość zapisu nie podważa w tym wypadku waloru świadectwa.

Zeznanie, świadectwo, autobiograficzne wspomnienie - to formy wypowiedzi zakładające wierność faktom, często traktowane bywają jako źródła historyczne ${ }^{29}$. To z powodu takiego właśnie ujmowania książki Niebo bez ptaków jej autorka, Danuta Brzosko-Mędryk, zeznawała w procesach nazistowskich zbrodniarzy Majdanka. Wspomnianym typom tekstów przysługuje domniemanie autentyczności spisanych faktów. I do takiej czytelniczej strategii odwołuję się w niniejszym artykule.

Unikam natomiast formułowania uogólnionych ocen. Mój sceptycyzm wynika z trzech przesłanek. Po pierwsze, pamięć ludzka jest subiektywna i selektywna. Uwaga ta dotyczy także zeznań składanych przed komisją przyjmującą więźniarki w Szwecji. Pewne ograniczenie zakresu opowieści wynika także z procedury i wpisanych $w$ nią zagadnień. Zeznająca jest pytana przede wszystkim o swoje indywidualne doświadczenie, co wiąże się z celem, w jakim spisuje się relacje, protokoły zeznań miały bowiem służyć jako dowody zbrodni w przyszłych procesach przeciwko nazistom. Po drugie, zakładam możliwość przemilczenia. Po trzecie, więźniarki miały ograniczoną perspektywę oglądu obozu, co wynika z usytuowania w hierarchicznej strukturze lagru, umiejscowienia przestrzennego, przebywania w bloku wielonarodowym czy jednoetnicznym, wreszcie z kondycji fizycznej i psychicznej. Szczególnie istotny jest też okres uwięzienia w Ravensbrück.

W przypadku wspomnień publikowanych w PRL-u musimy pamiętać, iż poruszany w nich problem polsko-żydowskich relacji był przedmiotem polityki komunistycznego państwa. Relacje więźniarek ukazywały się w czasie, w którym proces wydawniczy był ściśle kontrolowany. Ważny jest tu rok publikacji. Warto też pamiętać, iż im później po wojnie ukazuje się książka, tym większa możliwość nieświadomych nawet zapożyczeń z innych opracowań, pamięć indywidualna spotyka się bowiem wtedy z utrwaloną społeczną pamięcią o Ravensbrück. Ponadto, tak jak i w przypadku zeznań, musimy przyznać autorkom prawo do selektywnego milczenia, wyparcia niektórych

29 Zob. Dzieto literackie jako źródto historyczne, red. J. Sławiński, Z. Stefanowska, Warszawa 1978; B. Krupa, Wspomnienia obozowe jako specyficzna odmiana pisarstwa historycznego, Kraków 2006. 
przeżyć. Nie zawsze akt pisania, a zwłaszcza pisania z przeznaczeniem do publikacji, prowadzi do przepracowania traumy. Istotne są też ideologiczne i światopoglądowe motywacje autorek. W sposobie postrzegania żydowskiego losu ważny jest bagaż doświadczenia, z jakim Polki przybywały do Ravensbrück. Czy trafiają tu wprost $\mathrm{z}$ łapanek, z katowni gestapo, czy po wcześniejszym pobycie w innych obozach koncentracyjnych? Wiele z nich trafiło tu z Majdanka i Auschwitz. Część z tych więźniarek była świadkiniami akcji Erntefest ${ }^{30}$ w KL Lublin czy mordowania Żydów w komorach gazowych Birkenau.

Zarówno w wielu zeznaniach składanych przez Polki w Szwecji, jak i we wspomnieniach spisywanych po latach w Polsce obecność Żydówek nie została w ogóle odnotowana lub znajduje się w nich jedynie wzmianka o przybyciu żydowskiego transportu. Trudno natrafić na obszerniejszą informację czy zindywidualizowany portret. Należy także uwzględnić psychiczny proces przyzwyczajania się więźniów obozów koncentracyjnych do obrazów śmierci, w niektórych okresach masowa śmierć więźniarek z powodu osłabienia i chorób była w Ravensbrück zdarzeniem codziennym. Sytuacje takie zdarzały się zwłaszcza w roku 1942, gdy w całym obozie panował głód, związany z niskimi plonami w niemieckim rolnictwie, a także przy końcu roku 1944 i w pierwszych miesiącach 1945 roku, kiedy to nawet Niemcy doznawali głodu. O reakcji więźniów w obozach koncentracyjnych na powszechność śmierci pisze Antoni Kępiński: „Z czasem tępieli na widoki, które by dawniej wywoływały gwałtowny odruch grozy lub obrzydzenia; tępieli też na własny ból i cierpienia" ${ }^{31}$. Żydowska śmierć to codzienny pejzaż obozu nazistowskiego. Wszechobecność tej śmierci dodawała grozy każdemu lagrowi, a z drugiej strony znieczulała nieżydowskich więźniów, czyniła ich obojętnymi na cudzy los. Nie była niczym wyjątkowym. We wspomnieniach Janiny Augustynowicz czytamy: „Majestat śmierci niknął i malał, jak gdyby przestawał istnieć na tym olbrzymim kwadracie odrutowanej ziemi" ${ }^{32}$.

Obóz Ravensbrück w polskiej pamięci stał się obozem szczególnym ze względu na eksperymenty pseudomedyczne przeprowadzane tam na polskich więźniarkach politycznych. Wiele świadectw mówi o solidarności współwięźniarek, które ukrywały operowane kobiety przed władzami obozu, ratując je niejednokrotnie przed egzekucją. Spotkamy też wspomnienie, w którym autorka pisze, iż uciekające przed funkcyjnymi „króliczki” uratowane zostały przez stojące na apelu Żydówki ${ }^{33}$.

30 Zob. Krwawa środa. 3 listopada 1943 roku w pamięci świadków, wybór wspomnień i oprac. K. Czuryszkiewicz, B. Siwek-Ciupak, Lublin 2013; oraz naukowe opracowanie Erntefest. Zapomniany epizod Zagtady 3-4 listopada 1943, red. W. Lenarczyk, D. Libionka, Lublin 2009.

31 A. Kępiński, Rampa. Psychopatologia decyzji [w:] tegoż, Refleksje oświęcimskie, wybór i wstęp Z.J. Ryn, Kraków 2005.

32 J. Augustynowicz, Jacek $w$ Ravensbrück, Warszawa 1972, s. 96.

33 „Do obozu przychodziły transporty z ewakuowanego Oświęcimia. Pamiętam taki apel, kiedy kazano odejść do pracy kobietom Krasnej Armii, a Francuzkom do bloku 24. Pozostały 
Jest rzeczą naturalną, iż autorki opisują własne doświadczenia, przedstawiają swoje cierpienia, co ma również uzasadnienie psychologiczne. Szerszy ogląd obozu - nie bójmy się tego powiedzieć - wymaga nie tylko rzeczywistych możliwości obserwacji, ale także pewnego talentu intelektualnego oraz zdolności budowania narracji.

W relacjach zebranych w tomie Serca niezagaste o żydowskim losie mówi tylko jedna z 34 autorek. To krótka, lecz przejmująca relacja Kazimiery Chrobakowej o Żydówkach, którym w obozie mordowano dzieci3 ${ }^{34}$. Książka została wydana przez Wydawnictwo MON-u w latach 1975 i 1979. W tym wypadku za wyborem konkretnych wspomnień kryły się najprawdopodobniej względy ideologiczne, co uniemożliwia stawianie jednoznacznych tez. Zwraca jednakże uwagę to, że w książce z 2017 roku Przetrwatam. Doświadczenia kobiet więzionych $w$ czasach nazizmu i stalinizmu sytuacja wygląda podobnie. Znajdujemy tu jednozdaniowe stwierdzenia o obecności Żydówek w obozie lub wzmiankę o przybyłych transportach. Za modelową relację można uznać opowieść Anny Burdówny ${ }^{35}$, uwięzionej w Ravensbrück już 10 kwietnia 1940 roku. Jej wspomnienia obejmują pięciu lat i trzydzieści stron drukowanego pisma. Nie znajdziemy tu ani jednego słowa o Żydówkach, zostały z relacji czy autorskiej pamięci skutecznie wymazane. Tylko śladowe wzmianki o więźniarkach żydowskich spotkamy w bardzo obszernym zeznaniu Marii Moldenhawer, która $\mathrm{z}$ aresztu w Tarnowie przewieziona została do Ravensbrück w połowie września 1941 roku, a obóz opuściła w ewakuacyjnym transporcie do Szwecji 28 kwietnia 1945 roku. Pojawią się w jej relacji prostytutki żydowskie ${ }^{36}$ i uwaga o transporcie Żydówek węgierskich. Zeznająca nie odnotowuje wymordowania Żydówek w początku 1942 roku, pisząc o marszu śmierci z Auschwitz, nie wspomina o żydowskich kobietach, a stanowiły one zdecydowaną

na apelu tylko Polki, a wśród nich i »króle«. Wtem zbliża się [nieczytelne słowo] policjantek i otaczają nas. Pada hasło "króle uciekły« i wpadły do stojących dziesiątkami Żydówek. Było ich około 2 tysiące. Błyskawicznie utworzyły tłum, w który wmieszały się "króle«". M. Grabowska, Grupa doświadczalnie operowanych w ostatnich miesiacach obozu w Ravensbrück [w:] Ravensbrück. Wspomnienia dla pamięci pokoleń, oprac. A. Burdówna i in., Łódź 1970, s. 92. Karolina Lanckorońska, referując „obronę »królików « w najbardziej krytycznym momencie”, przypisuje decydującą rolę „krasnoarmiejkom”, które wyłączyły światło i wpuściły ofiary eksperymentów pomiędzy swoje szeregi na placu apelowym. Zob. K. Lanckorońska, Wspomnienia wojenne, wstęp L. Kalinowski, E. Orman, Kraków 2003, s. 316. W obu relacjach zapewne chodzi o tę samą akcję więźniarek.

${ }^{34}$ K. Chrobakowa, Ostatnia selekcja [w:] Serca niezagaste. Wspomnienia więźniarek z Ravensbrück, wyb. M. Kogut-Piotrowska, A. Gierczak, oprac. A. Gierczak, wstęp J. Zaborowski, Warszawa 1979, s. 181-189.

35 Zob. Relacja Anny Burdówny [w:] Przetrwatam. Doświadczenia kobiet więzionych w czasach nazizmu i stalinizmu, wyb., oprac. M. Buko, K. Madoń-Mitzner, M. Szymańska, Warszawa 2017, s. 30-60.

${ }^{36}$ Maria Moldenhawer, zeznanie nr 420, s. 9, zarchiwizowane w Bibliotece Uniwersyteckiej w Lund, http://www.ub.lu.se/witnessing-genocide, dostęp: 2.04.2018. 
większość jego przymusowych uczestniczek. Zauważmy też, że od sierpnia 1944 roku w lagrze panował chaos i po obozie, jak pisze Helm, „plątały się” grupki żydowskich kobiet, które odłączyły się od transportów ${ }^{37}$.

Dominującą zatem figurą Żydówki w relacjach Polek z Ravensbrück byłaby figura nieobecności. Jej wariantem wydaje się wspomnienie pożydowskich łachów, w jakie odziewano więźniarki. To widome ślady, dowody mówiące o wymordowaniu żydowskich kobiet. Najpierw były to ubrania więźniarek z Ravensbrück, potem odzież z transportów po zagazowanych w komorach Auschwitz-Birkenau.

\section{IV}

Spośród dziesiątek relacji polskich więźniarek z Ravensbrück chcę wskazać te wspomnienia, w których autorki dostrzegają i odnotowują odrębny los żydowskich kobiet. Wyróżniam trzy książki już tu przywołane: Janiny Fabierkiewicz-Szyrkowej Gdzie nie śpiewaty ptaki..., Karoliny Lanckorońskiej Wspomnienia wojenne, Zofii Krzyżanowskiej Czarna flage, a także Marii Rutkowskiej-Kurcyuszowej Kamyki Dawida ${ }^{38}$. Wydaje się, że w wypadku wspomnień Lanckorońskiej i Rutkowskiej-Kurcyuszowej mamy do czynienia z podwójną motywacją ich powstania. Zapewne - tak jak i w dwu pozostałych - prymarna jest tu funkcja świadczenia o historii i własnym życiu. Na planie prywatnej biografii uwidacznia się też konieczność usprawiedliwienia siebie, wytłumaczenia swoich poczynań innym.

Janinę Fabierkiewicz-Szyrkową aresztowano w marcu 1941 roku za konspiracyjną działalność w Związu Walki Zbrojnej. Do obozu w Ravensbrück, po przesłuchaniach przez gestapo, wysłano ją we wrześniu. Jako skazana na śmierć więźniarka polityczna przypisana została do grupy „króliczek”. Ostatecznie nie poddano jej „eksperymentowi medycznemu”, ale uwięziona w bunkrze spędziła w nim ponad pięć miesięcy. Tematyka jej wspomnień wykracza poza imperatyw opowiedzenia jedynie swojego losu. W jej relacji odnajdziemy wiele spostrzeżeń dotyczących sytuacji Żydówek. Odnotuje wydawanie im o połowę mniejszych racji żywnościowych, zauważy początek akcji „oczyszczania” obozu z Żydówek na początku 1942 roku. Przygląda się wzmożonemu napływowi transportów kobiet z całej Europy, w tym Żydówek, w ostatnim roku istnienia obozu. Uwięziona w bunkrze porozumiewa się z żydowskimi więźniami Sonderkommanda obsługującymi krematorium. Nosi na sobie odzież po zamordowanych Żydach: „Od chwili osadzenia

37 S. Helm, dz. cyt., s. 624.

${ }^{38}$ M. Rutkowska-Kurcyuszowa, Kamyki Dawida. Wspomnienia z pensji Panny Plater. Obóz Wielkiej Polski. Obóz Narodowo-Radykalny w obronie Warszawy 1939. FKL Ravensbrück, Katowice 2005. 
mnie w bunkrze chodzę w zielonej dżersejowej sukience pożydowskiej z naszytym na plecach czerwonym iksem" ${ }^{39}$. Jedno- i dwuzdaniowych uwag możemy odnaleźć w tekście więcej. Ale nawet i w tej empatycznej relacji Polki to Żydówki służą jako negatyw polskiej postawy godnościowej. Fabierkiewicz pisze o solidarnościowej postawie „naszych” blokowych i sztubowych, które, „poza nielicznymi wyjątkami” - zdały egzamin „chroniąc, broniąc, uprzedzając, opiekując się więźniarkami, ułatwiając im życie w obozie" ${ }^{40}$. Natomiast kiedy zdaje relacje o żydowskim bloku, zwraca uwagę na postawę funkcyjnych, które „maltretowały swoje rodaczki, pędziły je do roboty, wrzeszczały na nie i poszturchiwały - były często gorliwsze niż ich mocodawcy"41. Obserwacja ta poprzedzona jest zdaniem wprowadzającym, mówiącym o negatywnych postawach w obozie, o terrorze, strachu, głodzie, który robił z ludzi „szmaty”. Odnotowuje: „takie zjawiska obserwowałyśmy między innymi na blokach żydowskich"42.

Hrabina Karolina Lanckorońska przewieziona została do Ravensbrück 9 stycznia 1943 roku. Po okresie kwarantanny rozpoznano ją jako polską arystokratkę i umieszczono w tak zwanym bunkrze, gdzie przebywała w bardzo dobrych - jak na obóz koncentracyjny - warunkach. Po kilku miesiącach została sztubową na bloku więźniarek z Armii Czerwonej, a od 5 grudnia blokową w bloku Żydówek i Francuzek. Przez te ostatnie była po wojnie piętnowana jako współpracownica obozowego SS. Francuzki oskarżały ją o wskazywanie Niemcom ukrywających się rodaczek ${ }^{43}$. Duży fragment wspomnień Karolina Lanckorońska poświęciła relacji z pełnienia funkcji blokowej i odparciu zarzutów o wysługiwanie się władzom obozu ${ }^{44}$. Był to też blok żydowski. Jak pisze: „Do Żydówek, jako do osób szczególnie przez Niemców prześladowanych, odnosiłam się z góry optymistycznie, mając w pamięci swoją pracę sanitariuszki

39 J. Fabierkiewicz-Szyrkowa, dz. cyt., s. 183.

${ }^{40}$ Tamże, s. 90.

${ }^{41}$ Tamże, s. 88.

${ }^{42}$ Tamże. Tej diagnozie możemy przeciwstawić opinię Agassi: „In the course of this research, I learned about another form of heroism from both survivors and written memoirs: in innumerable small groups or "camp families", Jewish Ravensbrück prisoners developed form of mutual help, support, and responsibility that should consider heroic". Zob. taż, dz. cyt., s. 14 .

43 Zob. S. Helm, dz. cyt., s. 498, 732-734. O tego typu oskarżeniach formułowanych wobec niej pisze wprost Karolina Lanckorońska. Zob. taż, dz. cyt., s. 329.

${ }^{4}$ Niewątpliwie taką funkcję pełni następujący fragment: „Kiedy po rozdaniu rzeczy znów się żegnałyśmy, przycisnęła się do mnie starsza, siwowłosa Francuzka. Pamiętam, że była akuszerką i nazywała się bardzo banalnie, zdaje się, że Madame Durand. "Madame Karla, jestem z bloku 27 i wiem, ile się pani nacierpiała przez Francuzki. Patrzyłam na wszystko, co się tam działo, i na to, jak się pani rozchorowała. Dziś jestem tutaj i wiem, co mnie czeka, tak samo jak i pani wie. Niech mi pani powie, że pani do mnie osobiście żalu nie ma, przecież ja pani nigdy krzywdy nie zrobiłam «. Pamiętam ją doskonale, była zawsze dobra i miła, toteż trudno mi opisać wzruszenie, które mnie w owej chwili ogarnęło". K. Lanckorońska, dz. cyt., s. 324. 
w obozie lwowskim”45. Tymczasem blok Żydówek gromadził bardzo różnorodną społeczność kobiet. Więźniarki pochodziły z wielu państw, były zróżnicowane klasowo i kulturowo. Po rezygnacji ze składania skarg na wię́niarki do niemieckich władz obozu i z „brutalnej siły pałki” nie miała - jak pisze poza własnym autorytetem, żadnej możliwości wprowadzenia dyscypliny ${ }^{46}$. Mówi też o ratowaniu Żydówek i Francuzek we współpracy z czeską lekarką Zdenką Nedvedovą-Nejedlą ${ }^{47}$.

Literatura obozowa zapełniona jest relacjami o bestialstwie i cierpieniu. Przytaczam tu jeden tylko opis konkretnej sytuacji z książki Lanckorońskiej, gdyż zdarzenie to zostało odnotowane także w kilku innych wspomnieniach:

Wszystko jednak było niczym wobec tego, co się działo w namiocie. Umieszczono tam późną jesienią przeszło 4000 kobiet z ewakuowanego Oświęcimia, głównie Żydówki węgierskie. Nie było tam czym oddychać, bo nie było powietrza, nie było gdzie się położyć, bo nie było miejsca, nie było gdzie się załatwić, bo nieliczne, prowizoryczne ustępy były nie do użycia. Wyciekały więc spod namiotu strumienie moczu i kału, tworząc wkoło jakby wieniec cuchnących kałuż. Poza tym wydobywały się stamtąd wycia i krzyki 4000 kobiet, nieprzerwanie ani dniem, ani nocą, które się rozlegały na cały obóz ${ }^{48}$.

Obok Lanckorońskiej o losie tych kobiet pisze także Maria Wysznacka ${ }^{49}$. Przed węgierskimi Żydówkami do stojącego na obozowym placu namiotu kierowano kobiety przywiezione po klęsce powstania warszawskiego. Los innego, z lutego 1945 roku, transportu Żydówek uwięzionych w namiocie przedstawia też Wanda Dobaczewska ${ }^{50}$.

Maria Rutkowska-Kurcyuszowa z Suchenich jest autorką relacji Kamyki Dawida. Wspomnienia zanotowane w latach sześćdziesiątych wydane zostały w roku 2005. Tak długi dystans dzielący opisywane wydarzenia od czasu ich spisania i publikacji wynika bez wątpienia z powodów politycznych. Młoda idealistka, działaczka ONR-u, była pod urokiem i wpływem Jana Mosdorfa, jednego z ideowych przywódców tej nacjonalistycznej organizacji. Jej pierwszy mąz - Tadeusz Rutkowski - aresztowany w 1944 roku, został stracony w Gross-Rosen. W 1947 roku wyszła za mąż za dawnego towarzysza walki z ONR-u, dr. Jerzego Kurcyusza. Więźniarka Ravensbrück, Maria Rutkowska, przechodzi na kartach wspomnień polityczną przemianę. Wstydzi się polskiego antysemityzmu, wyraża przekonanie, iż Polacy nigdy nie poszliby drogą

\footnotetext{
45 Tamże, s. 281.

46 Tamże, s. 282.

47 Tamże, s. 286.

48 Tamże, s. 304.

49 M. Wysznacka, dz. cyt., s. 40-41.

50 W. Dobaczewska, Kobiety z Ravensbrück, dz. cyt., s. 159.
} 
okrucieństw Hitlera ${ }^{51}$ a poznanej w obozie Żydówce wyjaśnia, że jej obawa ujawnienia prawdziwej narodowej tożsamości właśnie Polce jest wręcz obrazą, bowiem jak mówi:

Antysemityzm był u nas pojmowany jako walka dwóch równych sobie stron o lepsze miejsce w życiu. Ale straszne byłoby dziś pomyśleć, że akceptując prawo do tej walki można było choć $\mathrm{w}$ jednym polskim sercu dopuścić do rozbudzenia nieludzkich instynktów. Jeśli wyjdziemy stąd żywe, będziemy ja i ty, jednakowo baczyć, aby nasze dzieci nie zapomniały niczego z doświadczeń naszego pokolenia ${ }^{52}$.

Niewątpliwie Kamyki Dawida służą także obronie przedwojennej młodości i ideowych wyborów z czasu podziemnej działalności.

Zofia Krzyżanowska, autorka Czarnej flagi, trafiła do obozu z robót w Niemczech. Nie była zatem działaczką partyjną ani uczestniczką walk konspiracyjnego podziemia. Nie umieszczono jej też w bloku polskim, w którym polityczne więźniarki wspomagały się wzajemnie. Jej los w obozie to los „cywila”. Wielonarodowościowy barak, życie bez protekcji funkcyjnych i codzienna dramatyczna walka o przeżycie. Te wspomnienia odznaczają się dużymi walorami literackimi. Opisane zostają w nich żydowska dziewczynka i katowana bezlitośnie przez kolonkę inna młoda i piękna żydowska kobieta.

Ostatnie strony powieści opisują pobyt autorki w szwedzkim szpitalu. Leczy się w nim ona po uwolnieniu z obozu. Wraz z nią w szpitalnej sali leżą dwie pacjentki, losom których Krzyżanowska nadaje wymiar symboliczny. Podstawowe znaczenie ma tu fakt, iż przywołuje je na kartach zamykających jej opowieść o Ravensbrück. Pisze zatem o Żydówce Róży Grossbaum i bezimiennej kobiecie znajdującej się w stanie krańcowego zmuzułmanienia. Róża, będąca w ostrej psychozie, histerycznie powtarza, iż musiała swoje żywe jeszcze dziecko wrzucić do krematoryjnego pieca, a bezimienna kobieta umiera, nie odzyskawszy przytomności. Po jej śmierci personel szpitala wciąga na maszt czarną flagę, gdyż - jak tłumaczy szwedzka siostra - umarł człowiek. Anonimowa muzułmanka, więźniarka Ravensbrück, staje się w zakończeniu powieści Krzyżanowskiej figurą człowieka, co oczywiście może być odczytane także jako odpowiedź na pytanie Primo Leviego.

Polki w obozie Ravensbrück - jak kilkakrotnie wspomniałem - były ofiarami nazistowskich zbrodni i jednocześnie świadkiniami Holokaustu. Mając na uwadze szwedzkie relacje o trwałości antysemickich postaw wśród ocalałych polskich więźniarek, przyglądałem się ich zeznaniom i wspomnieniom. Co mówią nam one o losie i Zagładzie Żydówek? Zaskakująca większość Polek milczy, w ich relacjach żydowska kobieta jest nieobecna lub pojawia się w kilkuzdaniowych wzmiankach. Powodów milczenia może być wiele: skupienie

${ }^{51}$ M. Rutkowska-Kurcyuszowa, dz. cyt., s. 174.

52 Tamże, s. 217. 
się na swoim własnym losie, bariera językowa uniemożliwiająca komunikację, zobojętnienie na śmierć, uwięzienie w stereotypie etnicznym i politycznym, kondycja fizyczna i psychiczna ograniczająca funkcje poznawcze umysłu, umiejscowienie w obozie. W rezultacie otrzymujemy obraz niepełny, wymagający konfrontacji wielu źróde ${ }^{53} \mathrm{i}$ wstrzemięźliwości w formułowaniu uogólniających sądów. Tym cenniejszych jest tych kilka wskazanych relacji, w których autorki starają się świadczyć także o zbrodni Holokaustu.

\section{Bibliografia}

Agassi J.B., The Jewish Women Prisoners of Ravensbrück: Who Were They?, Lubbock, Texas, 2014.

Augustynowicz J., Jacek w Ravensbrück, Warszawa 1972.

Bauer Y., Przemyśleć Zagładę, tłum., J. Giebułtowski, J. Surewicz, Warszawa 2016. Brzosko-Mędryk D., „Mury” w Ravensbrück, Warszawa 1979.

Chrobakowa K., Ostatnia selekcja [w:] Serca niezagaste. Wspomnienia więźniarek $z$ Ravensbrück, wyb. M. Kogut-Piotrowska, A. Gierczak, oprac. A. Gierczak, wstęp J. Zaborowski, Warszawa 1979.

Dobaczewska W., Kobiety z Ravensbrück, Warszawa 1946.

Dobaczewska W., Spoteczeństwo nie z tej ziemi, Łódź 1979.

Dzieto literackie jako źródto historyczne, red. J. Sławiński, Z. Stefanowska, Warszawa 1978.

Erntefest. Zapomniany epizod Zagtady 3-4 listopada 1943, red. W. Lenarczyk, D. Libionka, Lublin 2009.

Fabierkiewicz-Szyrkowa J., Gdzie nie śpiewaty ptaki..., Warszawa 1972.

Giloh M., Odmienne sylwetki przybytych do Szwecji więźniów pochodzenia żydowskiego i nieżydowskiego, ocalatych z obozów koncentracyjnych na ziemiach polskich, „Zagłada Żydów. Studia i Materiały” 2012, nr 8.

53 Wśród setek relacji zwraca uwagę opowieść podana przez Eugeniusza S. Kruszewskiego w książce Mówią świadkowie Ravensbrück (wyb., wstęp, oprac. tenże, Kopenhaga 2001). Zeznaje Zofia Czajkowska, urodzona 22 grudnia 1910 roku w Sandomierzu: „Transport nasz był specjalnie maltretowany. Zarząd bloku, tzw. blokowa i sztubowe, były prostytutkami i miały polecone specjalnie brutalnie i okrutnie obchodzić się z nami. One dobrały sobie do pomocy osoby również okrutne, m.in. było parę Żydówek i kilka prostytutek z Częstochowy. One ułożyły sobie "system" maltretowania Polek" (tamże, s. 18). O jednym z polskim bloków, gdzie funkcyjnymi były polskie i żydowskie prostytutki, opowiada w swoim zeznaniu także Maria Moldenhawer. Zob. przypis 36. Najprawdopodobniej obie ocalone opisują tę samą sytuację. To jedyne znane mi relacje z Ravensbrück o znęcaniu się Żydówek (precyzyjniej mówiąc, prostytutek żydowskich) nad Polkami. Tak jak i w przytaczanych wcześniej świadectwach zakładam autentyzm relacjonowanej sytuacji. Niemniej jednak i w tym wypadku stronię od możliwych uogólnień. 
Grabowska M., Grupa doświadczalnie operowanych $w$ ostatnich miesiacach obozu w Ravensbrück [w:] Ravensbrück. Wspomnienia dla pamięci pokoleń, oprac. A. Burdówna i in., Łódź 1970.

Helm S., Kobiety z Ravensbrück. Życie i śmierć w hitlerowskim obozie koncentracyjnym dla kobiet, tłum. K. Bażyńska-Chojnacka, P. Chojnacki, Warszawa 2017.

Kępiński A., Refleksje oświęcimskie, wyb. i wstęp Z.J. Ryn, Kraków 2005.

Kiedrzyńska W., Ravensbrück. Kobiecy obóz koncentracyjny, Warszawa 1965.

Kłonczyński A., My w Szwecji nie porastamy mchem. Emigranci polscy w Szwecji w latach 1945-1980, Gdańsk 2012.

Krupa B., Wspomnienia obozowe jako specyficzna odmiana pisarstwa historycznego, Kraków 2006.

Krwawa środa. 3 listopada 1943 roku w pamięci świadków, wyb., oprac. K. Czuryszkiewicz, B. Siwek-Ciupak, Lublin 2013.

Krzyżanowska Z., Czarna flaga, Warszawa 1960.

Lanckorońska K., Wspomnienia wojenne, wstęp L. Kalinowski, E. Orman, Kraków 2003.

Mówią świadkowie Ravensbrück, wyb., wstęp, oprac. E.S. Kruszewski, Kopenhaga 2001. Mury. Harcerska konspiracyjna drużna $w$ Ravensbrück. Wspomnienia, materiaty do gawęd, oprac. J. Kantor, red. A. Szefer, Katowice 1986.

Persson S., Biate autobusy. Pakt z Himmlerem i niezwykta akcja ratowania więżiów obozów, tłum. Z. Kunert, Warszawa 2012.

Przetrwatam. Doświadczenia kobiet więzionych $w$ czasach nazizmu i stalinizmu, wyb., oprac. M. Buko, K. Madoń-Mitzner, M. Szymańska, Warszawa 2017.

Rutkowska-Kurcyuszowa M., Kamyki Dawida. Wspomnienia z pensji Panny Plater. Obóz Wielkiej Polski. Obóz Narodowo-Radykalny w obronie Warszawy 1939. FKL Ravensbrück, Katowice 2005.

Sterkowicz S., Kobiecy obóz koncentracyjny Ravensbrück, Włocławek 2006.

Truszkowska-Kuliniczowa A., Mój wiek XX. Wspomnienia, Szczecin 2004.

Woźniakówna M., Obóz koncentracyjny dla kobiet. Ravensbrück, Poznań 1946.

Wysznacka M., Bestie i ludzie (Ravensbrück-Szwecja), Włocławek 1947. 